\title{
Políticas públicas de recursos hídricos para o semi-árido
}

JOSÉ ALMIR CIRILO

\section{Introdução}

$\mathrm{P}$ ARA QUE o uso dos recursos naturais, particularmente terra, água e vegetação, ocorra de forma sustentável, é necessário que o processo de desenvolvimento aconteça com preservação da capacidade produtiva desses recursos. Quando são mal utilizados, a produtividade da agricultura é reduzida, os processos de desertificação avançam, os ecossistemas e mananciais hídricos tornam-se mais fragilizados, o sustento das populações se reduz, crescem a pobreza e o êxodo para as cidades maiores. Do ponto de vista social, para tanto, necessita-se de políticas públicas adequadas para que a criação de emprego e renda aconteça concomitantemente com outras políticas que assegurem a desejada racionalidade dos usos da água e dos recursos naturais de forma geral.

Assim, a sustentabilidade, para ocorrer, requer que a base de recursos naturais e do meio ambiente seja usada de maneira que a produtividade da terra possa pelo menos se manter e preferencialmente crescer ao longo do tempo. Portanto, as diversas formas de uso de terra e de água devem obedecer ao princípio de que o uso desses recursos não deve exceder sua capacidade de renovação.

A problemática dos recursos hídricos nas regiões semi-áridas mais habitadas é uma questão crucial para superação dos obstáculos ao desenvolvimento. É fato que os governos de muitas regiões semi-áridas do mundo vêm atuando com o objetivo de implantar infra-estruturas capazes de disponibilizar água suficiente para garantir o abastecimento humano e animal e viabilizar a irrigação. Todavia, esse esforço ainda é, de forma global, insuficiente para resolver os problemas decorrentes da escassez de água, o que faz que as regiões continuem vulneráveis à ocorrência de secas, especialmente quando se trata do uso difuso da água no meio rural. De qualquer modo, a ampliação e o fortalecimento da infra-estrutura hídrica, com adequada gestão, constituem requisitos essenciais para a solução do problema, servindo como elemento básico para interiorização do desenvolvimento.

\section{O Nordeste semi-árido}

A expressão semi-árido normalmente é usada para descrever o clima e as regiões onde ocorrem precipitações médias anuais entre 250 e $500 \mathrm{~mm}$ e cuja vegetação é composta prioritariamente por arbustos que perdem as folhas nos meses mais secos ou por pastagens que secam na época de estiagem. Vegetação 
característica de regiões semi-áridas são, por exemplo, as estepes, como as do Cazaquistão, e a caatinga, presente apenas no Nordeste do Brasil.

Conforme descrição apresentada por Cirilo et al. (2007, p.33), a Região Nordeste do Brasil ocupa a posição norte-oriental do país, entre $1^{\circ}$ e $18^{\circ} 30^{\prime}$ de latitude Sul e 3430' e 4020' de longitude Oeste de Greenwich. Sua área, que é de $1.219 .000 \mathrm{~km}^{2}$, equivale a aproximadamente um quinto da superfície total do Brasil, abrangendo nove Estados (Maranhão, Piauí, Ceará, Rio Grande do Norte, Paraíba, Pernambuco, Alagoas, Sergipe e Bahia). Na região vivem 18,5 milhões de pessoas, dos quais 8,6 milhões estão na zona rural.

Tendo em vista a necessidade de reavaliação dos limites da região semi-árida do Nordeste, trabalho desenvolvido pelo Ministério da Integração Nacional (Brasil, 2005, 2007) acrescentou, aos 1.031 municípios incorporados nos limites até então vigentes, outros 102 novos municípios enquadrados em critérios estabelecidos (precipitação, índice de aridez e risco de secas). Daí, a área classificada oficialmente como semi-árido aumentou de $892.309,4 \mathrm{~km}^{2}$ para $969.589,4 \mathrm{~km}^{2}$. A Figura 1 apresenta os limites dos municípios inseridos na nova delimitação do semi-árido e subúmido seco nordestino.

O Nordeste semi-árido é uma região pobre em volume de escoamento de água dos rios. Essa situação pode ser explicada em razão da variabilidade temporal das precipitações e das características geológicas dominantes, onde há predominância de solos rasos baseados sobre rochas cristalinas e conseqüentemente baixas trocas de água entre o rio e o solo adjacente. O resultado é a existência de densa rede de rios temporários. A maior exceção é o Rio São Francisco. Esse grande rio, porém, nasce na Serra da Canastra, em Minas Gerais, e só após centenas de quilômetros de percurso entra na região Nordeste.

Outros rios permanentes são encontrados no Maranhão, no Piauí e na Bahia, com destaque para o Rio Parnaíba. Os rios de regime temporário são encontrados na porção nordestina que se estende desde o Ceará até a região setentrional da Bahia. Entre esses, destaca-se o Jaguaribe, no Ceará, pela sua extensão e potencial de aproveitamento: em sua bacia hidrográfica se encontram alguns dos maiores reservatórios do Nordeste, como Castanhão e Orós.

\section{Potencialidades hídricas regionais - águas superficiais}

A potencialidade hídrica superficial é representada pela vazão média de longo período em uma seção de rio. Trata-se de um indicador importante, pois possibilita uma primeira avaliação da carência ou abundância de recursos hídricos de forma espacializada numa dada região.

A Figura 2 indica as potencialidades hídricas superficiais, expressas por unidade de área (indicadas em litros por segundo por quilômetro quadrado), nas diferentes bacias hidrográficas da região, como resultado dos estudos hidrológicos desenvolvidos para o trabalho da ANA/MMA - Atlas Nordeste - Abastecimento Urbano de Água (ANA, 2005). 


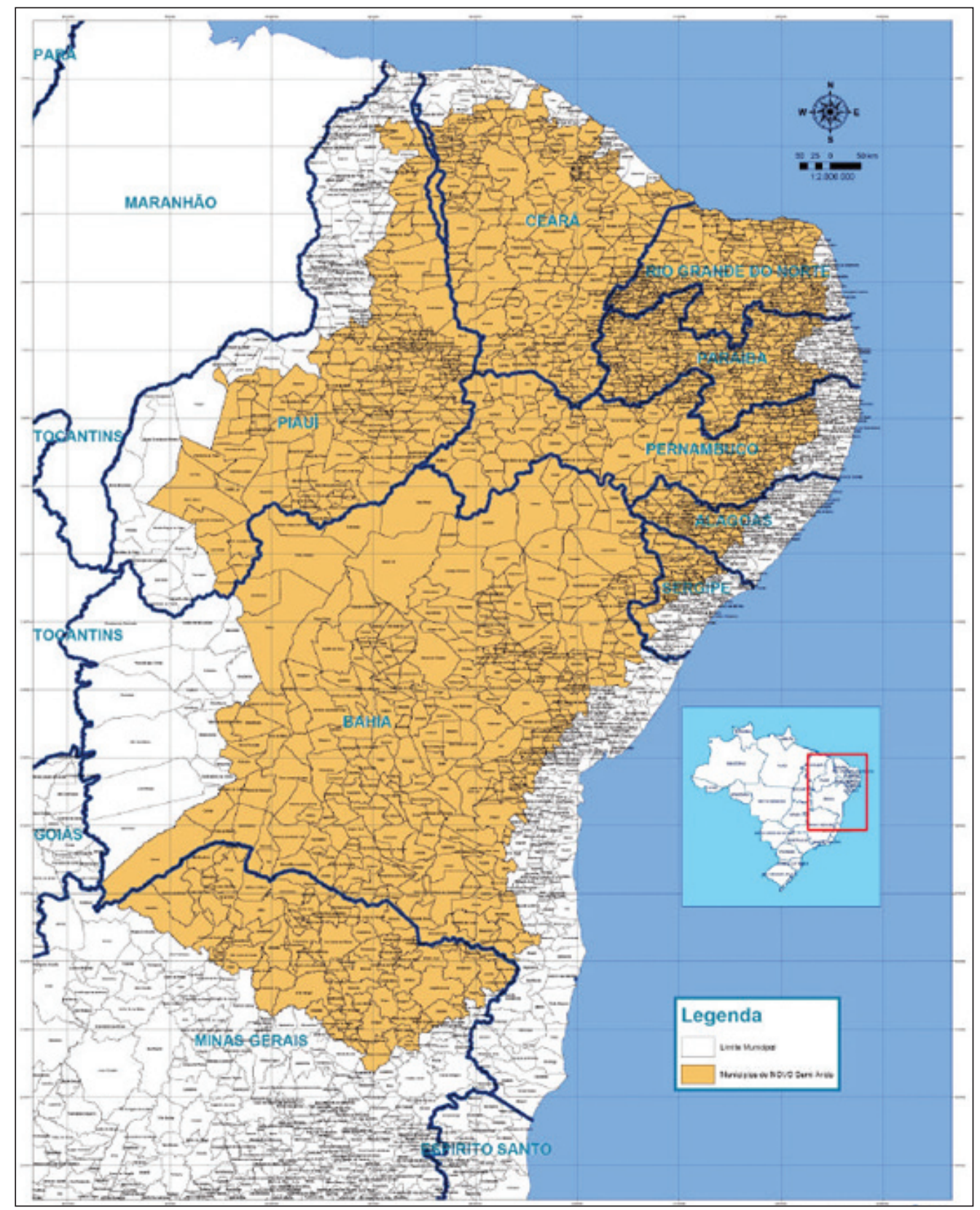

Fonte: Brasil (2005).

Figura 1

Nova abrangência da região semi-árida e subúmida seca do Nordeste do Brasil.

\section{Potencialidades hídricas regionais - águas subterrâneas}

Segundo Demetrio et al. (2007), aqüíferos são formações geológicas que têm a capacidade de armazenar e ceder água em quantidades que sejam economicamente viáveis de serem aproveitadas pelo homem. Por excelência, os aqüí- 


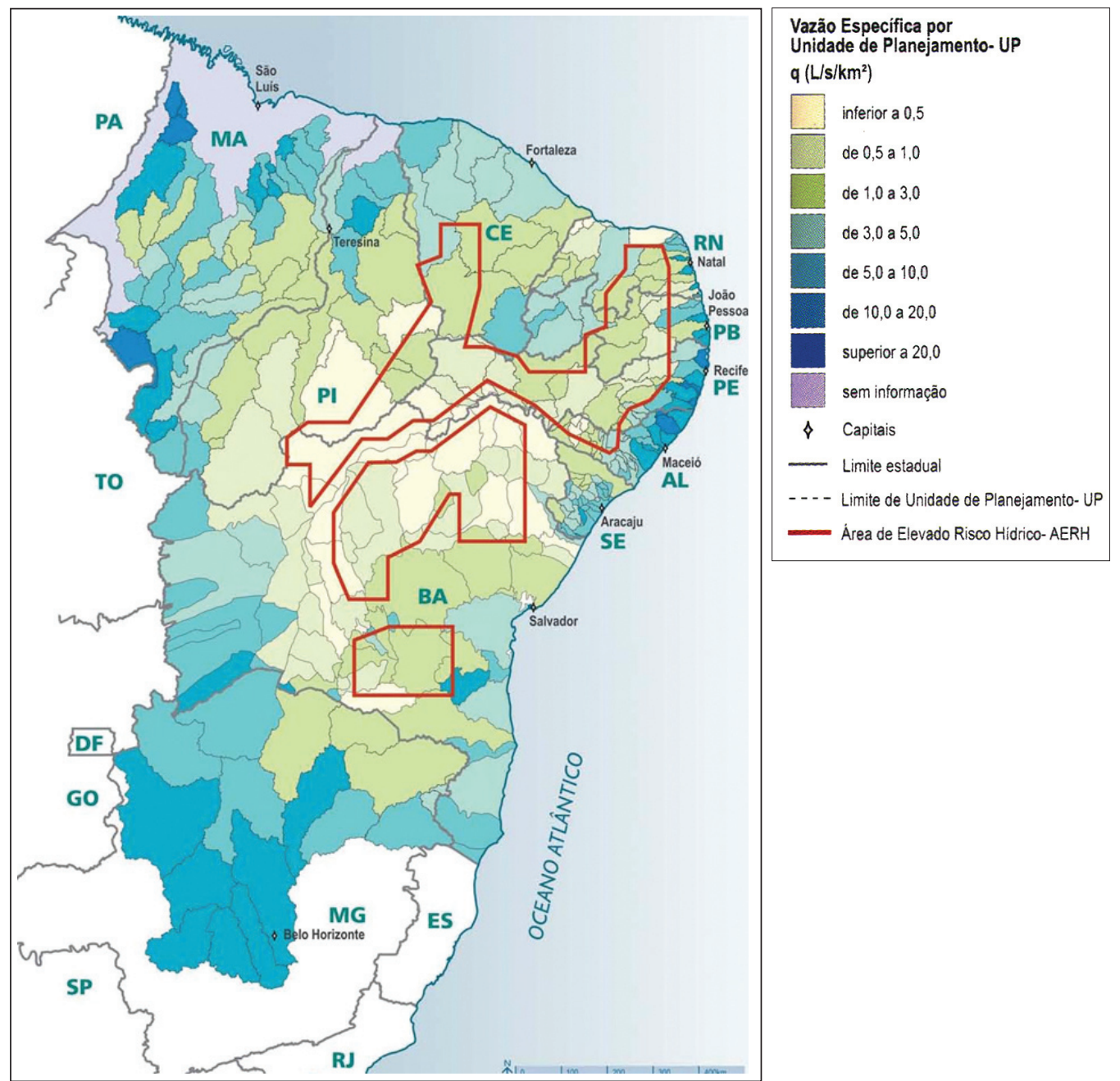

Fonte: ANA (2005).

Figura 2

Vazões específicas médias das bacias hidrográficas do Nordeste do Brasil.

feros são constituídos por sedimentos arenosos. Em princípio, uma rocha cristalina não formaria bom aqüífero, uma vez que os minerais que constituem essa rocha estão fundidos uns aos outros, ou seja, não há poros, pelo menos para fins práticos de acumulação de água. Porém, em razão dos esforços tectônicos, de diversas naturezas, essas rochas se quebram, formando fraturas ou juntas, e nos espaços abertos dessas feições estruturais a água se acumula.

No que se refere à ocorrência de águas subterrâneas, como o território nordestino é em mais de $80 \%$ constituído por rochas cristalinas, há predominância de águas com teor elevado de sais captadas em poços de baixa vazão, da ordem de $1 \mathrm{~m}^{3} / \mathrm{h}$. A exceção ocorre nas formações sedimentares, em que as águas normalmente são de melhor qualidade e se podem extrair maiores vazões, da ordem de dezenas a centenas de $\mathrm{m}^{3} / \mathrm{h}$, de forma contínua. 
A Figura 3 a seguir mostra, de forma esquemática, a ocorrência dos aqüíferos no Nordeste.

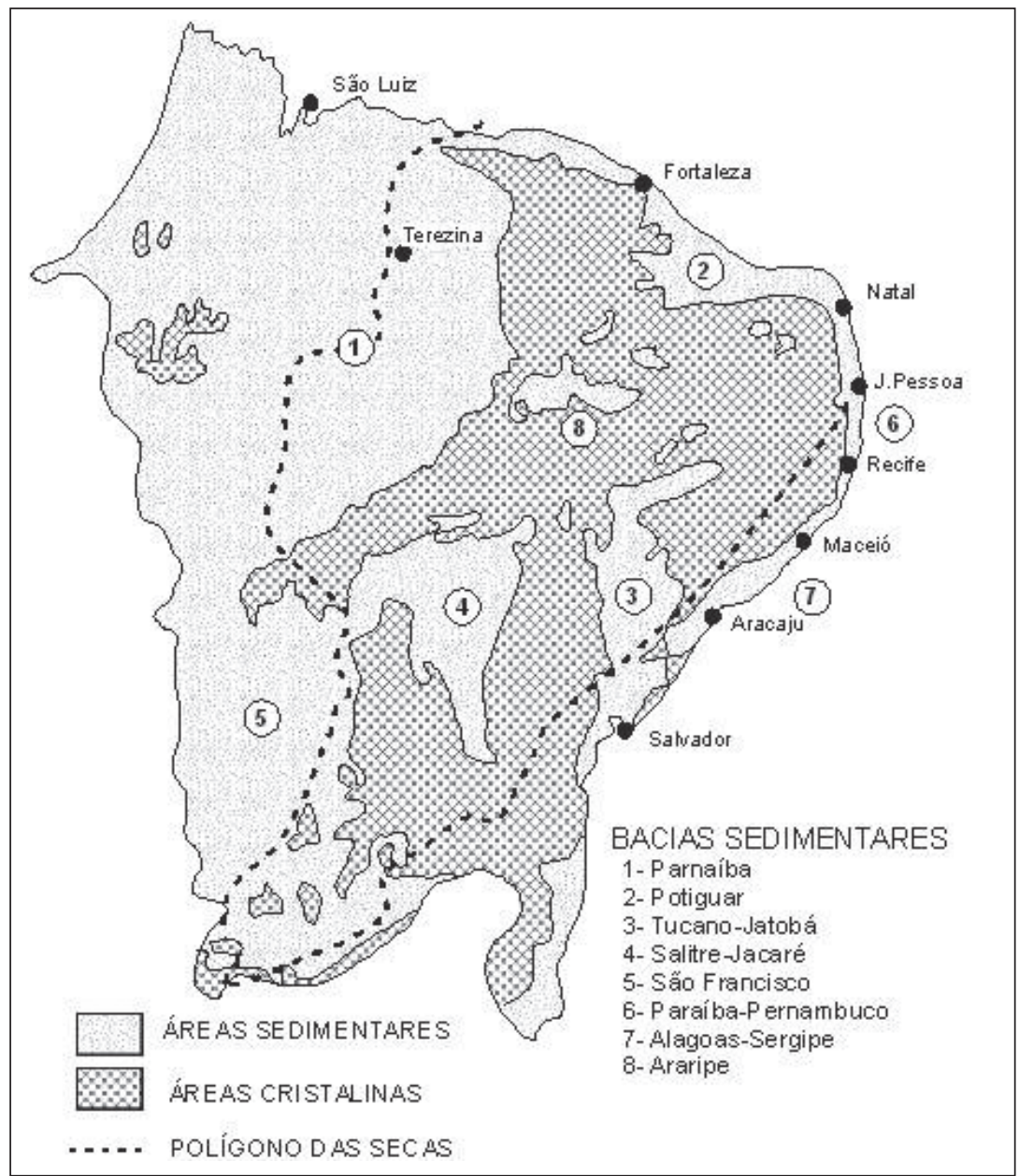

Fonte: Demetrio et al. (2007).

Figura 3

Distribuição das rochas sedimentares e cristalinas na área de abrangência do polígono das secas da Sudene.

Rebouças (1997), a partir de estudos anteriores, ressalta que as reservas de água doce subterrânea nas bacias sedimentares do Nordeste permitem a captação anual de vinte bilhões de metros cúbicos por ano, sem colocar em risco as reservas existentes. Esse volume equivale a $60 \%$ da capacidade do reservatório de Sobradinho, na Bahia (34 bilhões de metros cúbicos), principal responsável pela regularização das vazões do Rio São Francisco, ou o triplo da capacidade do açude Castanhão ( 6,7 bilhões de metros cúbicos). Trata-se, portanto, de volume considerável de água. É necessário ressaltar, no entanto, as peculiaridades dessas reservas:

- concentração espacial (no caso do semi-árido, Piaú e Bahia detêm os 
principais aqüíferos, no resto da região as ocorrências são de manchas sedimentares esparsas);

- em muitos lençóis a profundidade encarece o custo de implantação e operação dos poços (na Chapada do Araripe, município de Bodocó, no lado pernambucano, há um poço com 950 metros de profundidade e capacidade de $140 \mathrm{~m}^{3} / \mathrm{h}$, onde o nível dinâmico da água está a mais de 300 metros abaixo do terreno);

- existe muita incerteza sobre os mecanismos de recarga dos aqüíferos sedimentares do semi-árido, bem como a dimensão dessa recarga; por essa razão, uma exploração intensiva pode colocar em risco essas fontes.

Pelo exposto, as águas subterrâneas nas reservas sedimentares do semiárido nordestino devem ser usadas criteriosamente, de preferência para o abastecimento humano (diversas cidades do Nordeste situadas sobre as bacias sedimentares ou próximas a elas são abastecidas por essas fontes), e não faz sentido considerar que essa potencialidade seja capaz de atender às demandas regionais, até porque seriam necessárias grandes transferências de água para isso.

Agregando-se as potencialidades superficiais e subterrâneas, diversos estudos, a partir do PLIRHINE (Sudene, 1980), atualizados pelo Projeto Áridas (1994) e agrupados por Rebouças (1997, p.144), apresentam indicadores potenciais de quantidade de água por habitante por ano para as unidades de planejamento em que o PLIRHINE dividiu a região. Esses indicadores indicam regiões particularmente críticas como Leste da Paraíba ( $\left.1.030 \mathrm{~m}^{3} / \mathrm{hab} / \mathrm{ano}\right)$, Leste Potiguar (997 $\left.\mathrm{m}^{3} / \mathrm{hab} / \mathrm{ano}\right)$, Fortaleza $\left(846 \mathrm{~m}^{3} / \mathrm{hab} / \mathrm{ano}\right)$ e Leste de Pernambuco $\left(819 \mathrm{~m}^{3} / \mathrm{hab} / \mathrm{ano}\right)$. Considere-se o parâmetro estabelecido pela ONU de $1.500 \mathrm{~m}^{3} / \mathrm{hab} /$ ano como a quantidade potencial de água mínima para o bem-estar e desenvolvimento de qualquer região. Apesar da criticidade, existem regiões do mundo semi-árido com menor quantidade de água per capita, como Israel, onde, ainda conforme Rebouças (1997, p.144), se dispõe de apenas $370 \mathrm{~m}^{3} / \mathrm{hab} /$ ano, e mesmo assim se consegue padrão de produtividade agrícola muito superior ao semi-árido do Nordeste, graças à eficiência obtida como conseqüência do controle tecnológico, reúso das águas servidas, recarga de aqüíferos e outras ações.

Certamente, boas práticas dessas regiões são exemplos a serem seguidos. No entanto, é importante ressaltar as diferenças fisioclimáticas em relação ao Nordeste do Brasil. Diferenças básicas são, por exemplo, regime de chuvas mais uniforme e evaporação potencial muito menor, como é o caso de regiões da Europa, onde a precipitação média é inferior ao do semi-árido nordestino; solos mais profundos e possibilidade de recarga natural ou artificial dos aqüíferos eficiente, como ocorrem no meio-oeste americano; alto nível de tratamento de esgotos e conseqüentemente muito menor poluição das águas; existência de infra-estrutura de integração das bacias por obras hidráulicas, possibilitando melhor distribuição territorial da água. 
Um bom exemplo de eficiência, para o aproveitamento das potencialidades descritas antes, é dado pelo Salt River Project, no Estado norte-americano do Arizona. Aproveitando os solos cuja profundidade chega a 500 metros e as águas de degelo que escoam em certas épocas do ano, promove-se naquele projeto intensa recarga do aqüífero, tanto por inundação quanto por inversão de bombeamento ao longo dos canais, para aproveitamento da água durante todo o ano.

A Figura 4 mostra o Salt River e canais dele derivados.

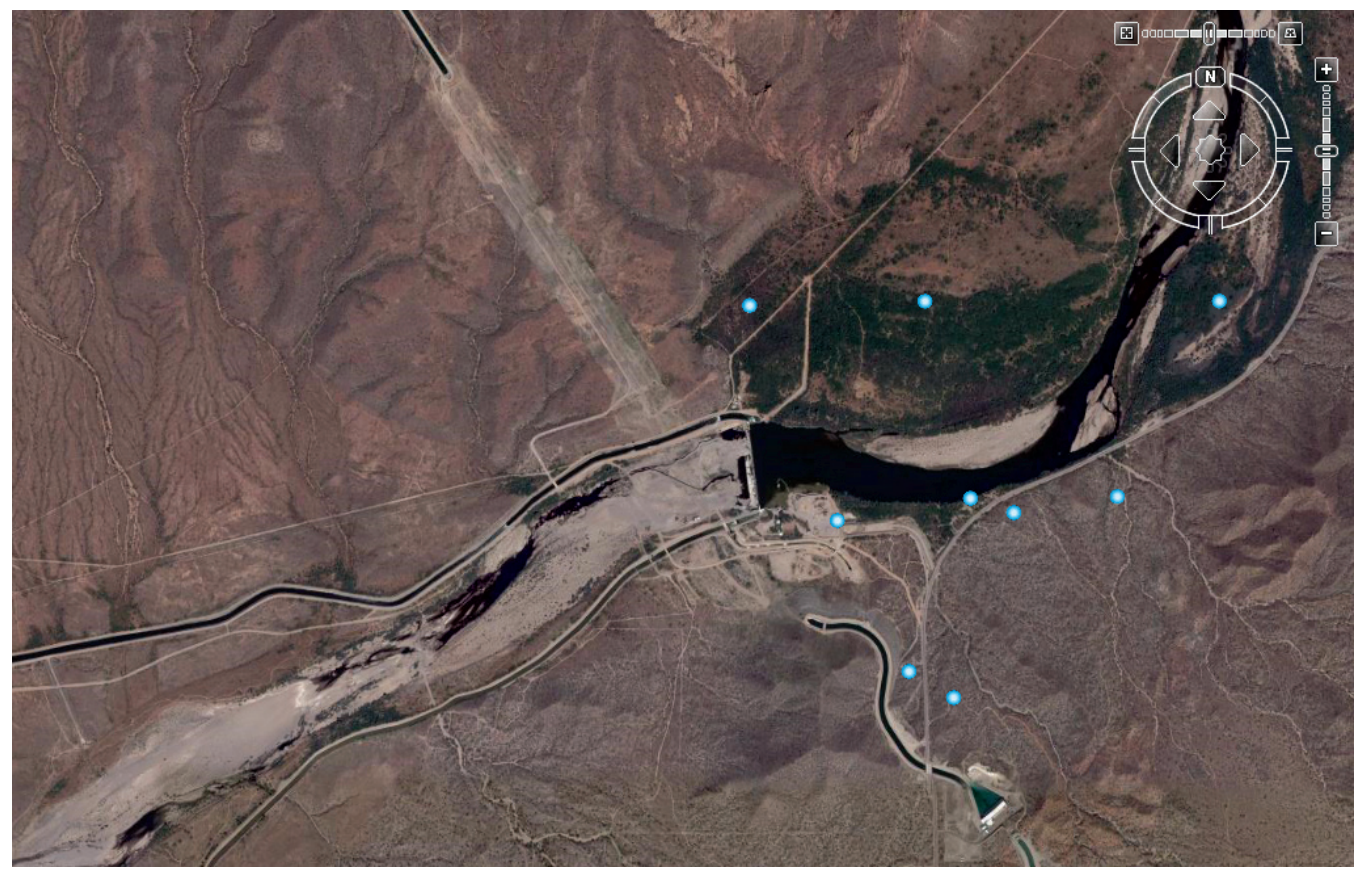

Fonte: Google Earth.

Figura 4

Barramento no Salt River, canais de derivação e área de recarga.

\section{Processos de desertificação no Nordeste}

A Convenção das Nações Unidas para o Combate à Desertificação (UNCCD) conceitua desertificação como o processo de degradação das terras em regiões áridas, semi-áridas e subúmidas secas, em decorrência de fatores como ação antrópica e mudanças climáticas. Essa degradação é a perda ou redução da produtividade econômica ou biológica dos ecossistemas secos, causadas pela erosão do solo, deterioração dos recursos hídricos e perda da vegetação natural.

De acordo com estudo do Ministério do Meio Ambiente (Brasil, 2002, p.42), as áreas do Nordeste com sinais extremos de degradação, os chamados "Núcleos de Desertificação", são Gilbués (PI), Irauçuba (CE), Seridó, fronteira entre os Estados da Paraíba e do Rio Grande do Norte, e Cabrobó (PE). Estimase que o processo de desertificação venha comprometendo uma área de 181.000 quilômetros quadrados, decorrente de impactos difusos e concentrados sobre o território da região. 
O Quadro 1 sinaliza que a área afetada de forma muito grave é de 98.595 quilômetros quadrados, o que corresponde a aproximadamente $10 \%$ da porção semi-árida, e 81.870 quilômetros quadrados de forma grave. As demais áreas sujeitas aos processos de desertificação - 393.896 quilômetros quadrados - sofrem degradação moderada.

A Figura 5 representa, no polígono do semi-árido, as áreas atingidas pelo processo de desertificação.

Quadro 1 - Áreas afetadas pela desertificação no Nordeste

\begin{tabular}{c|c|c|c|c}
\hline \multirow{2}{*}{ Estado } & \multirow{2}{*}{ Área total $\left(\mathrm{km}^{2}\right)$} & \multicolumn{3}{|c}{ Área afetada em termos absolutos $\left(\mathrm{km}^{2}\right)$} \\
\hline & & Moderada & Grave & Muito grave \\
\hline Alagoas & 27.731 & 6.256 & - & - \\
\hline Bahia & 561.026 & 258.452 & 10.163 & - \\
\hline Ceará & 148.016 & 35.446 & 16.366 & 26.993 \\
\hline Paraíba & 56.372 & - & 8.320 & 32.109 \\
\hline Pernambuco & 98.307 & - & 28.356 & 22.883 \\
\hline Piauí & 250.934 & 86.517 & - & 3.579 \\
\hline Rio Grande do Norte & 53.015 & 5.154 & 18.665 & 8.337 \\
\hline Sergipe & 21.994 & 2.071 & - & 4.692 \\
\hline Total & 1.217 .395 & 393.896 & 81.870 & 98.593 \\
\hline
\end{tabular}

Fonte: Brasil (2002, p.44).

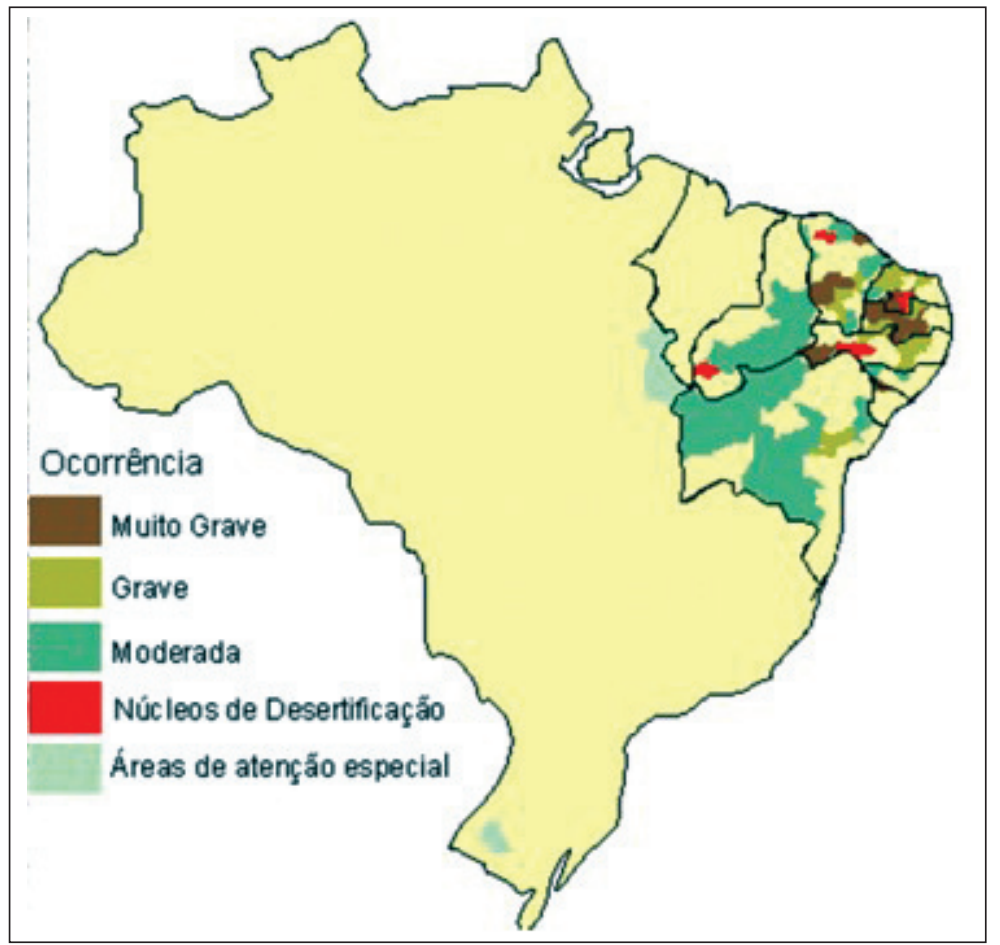

Fonte: Embrapa Semi-Árido.

Figura 5 - Desertificação: áreas afetadas. 
A superexploração dos recursos naturais nessa região tem efeitos de médio prazo sobre a qualidade ambiental na região, onde predominam como atividades econômicas as culturas de subsistência, a pecuária extensiva e alguns perímetros de agricultura irrigada. Muitas áreas irrigadas apresentam sinais de salinização, pela deficiência ou ausência de drenagem dos solos. Em cerca de 600 mil hectares irrigados no Nordeste, registram-se sinais de salinização e/ou compactação do solo em aproximadamente $30 \%$ da área.

\section{Impactos potenciais das mudanças climáticas}

Estudos recentes têm demonstrado uma alta correlação entre a ocorrência de eventos extremos (secas e cheias) em diferentes partes do planeta e o fenômeno denominado "El Niño", associado ao aumento da temperatura da água no oceano Pacífico. No Brasil, "El Niño" provoca grandes enchentes na Região Sul, nas bacias hidrográficas do Iguaçu, Itajaí, Uruguai e outras, e torna mais severa a seca na região semi-árida do Nordeste. Surge, então, a discussão sobre as causas dos eventos extremos, se naturais, se decorrentes da ação do homem.

O relatório do Intergovernmental Panel on Climate Change, denominado IPCC AR4 (disponível no site http://ipcc-wgl.ucar.edu/) sobre as mudanças climáticas conclui, com mais de $90 \%$ de confiança, que o aquecimento global dos últimos cinqüenta anos é causado pelas atividades humanas. Segundo Marengo (2007), os resultados desse estudo para a América do Sul indicam que as mudanças climáticas mais intensas para o final do século XXI, relativamente ao clima atual, vão acontecer na região tropical, especificamente Amazônia e Nordeste do Brasil. Essas duas regiões, portanto, são as mais vulneráveis do Brasil às mudanças de clima.

Numa atmosfera mais aquecida, de modo geral espera-se a ocorrência de precipitações pluviométricas mais intensas nas regiões mais úmidas, veranicos e ondas de calor mais freqüentes. Na região semi-árida, a maioria dos cenários de mudanças climáticas sinaliza para, com o aumento da temperatura, o aumento da evaporação nos corpos d'água e, conseqüentemente, redução do volume neles escoado; redução da recarga dos aqǘferos em até $70 \%$ até o ano 2050 e, portanto, da realimentação da vazão dos rios; concentração do período chuvoso em ainda menor espaço de tempo e com redução da precipitação (cenário pessimista: aumento da temperatura de 2 a $4^{\circ} \mathrm{C}$ e $15 \%$ a $20 \%$ a menos de chuva; cenário otimista: 1 a $3^{\circ} \mathrm{C}$ mais quente, $10 \%$ a $15 \%$ de redução de chuva); tendência de "aridização" da região, com a substituição da caatinga por vegetação mais típica de regiões áridas, como as cactáceas.

\section{A água como condicionante do desenvolvimento do Nordeste} Histórico das politicas públicas regionais

A política de acumulação de água em açudes, típica da região, tem sido feita sob duas formas. A primeira, em grandes reservatórios com capacidade de regularização plurianual, em bacias hidrográficas de maior porte. Esse tipo de reservató- 
rio, com capacidade da ordem do bilhão de metros cúbicos, encontra-se presente em diversos Estados da região, porém em pequeno número. A Figura 6 mostra o açude do Cedro, cuja construção foi iniciada em 1873, sob determinação do Imperador D. Pedro II, e concluída em 1906. A segunda política de acumulação de água decorre do emprego de pequenos reservatórios com capacidade da ordem de poucos milhares de metros cúbicos, os chamados barreiros, espalhados por toda a região. Os altos índices de evaporação potencial, da ordem de $2.500 \mathrm{~mm}$ ao ano, trazem sério problema à política de acumulação de água, especialmente à pequena açudagem, que não resiste aos efeitos da seca prolongada.

Além dos barreiros já citados, que ainda se constituem no tipo de obra mais executado para o atendimento da população rural difusa, os poços e cisternas rurais são as formas de captação e armazenamento de água mais comuns na região.

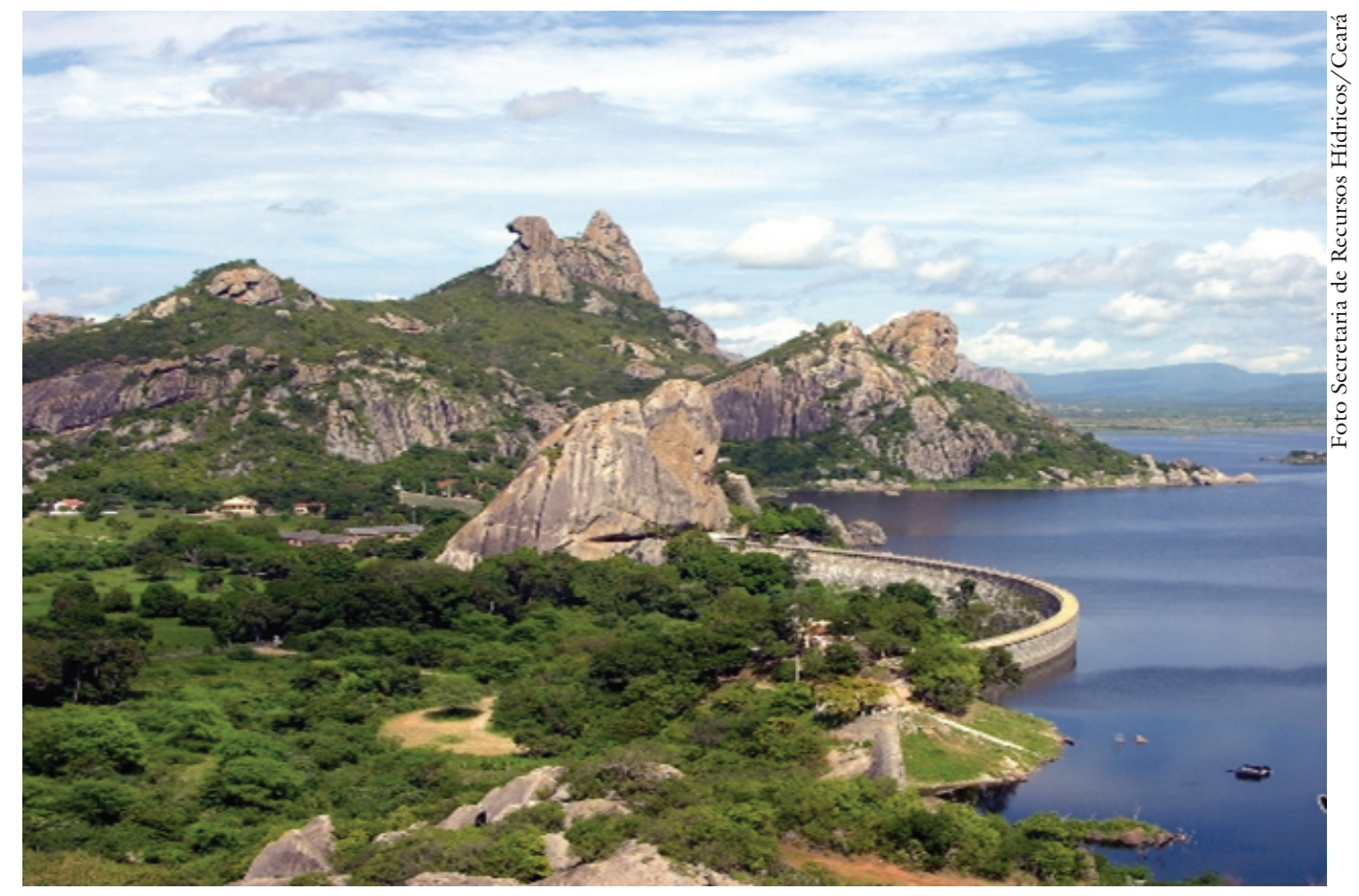

Figura 6 - Açude do Cedro, no Ceará.

No Nordeste do Brasil, estima-se que cerca de cem mil poços tenham sido perfurados. Pelo fato de a maior parte da região semi-árida do Nordeste ser constituída por formações cristalinas, a perfuração de poços como solução para o suprimento das diferentes necessidades está sujeita às seguintes limitações:

- baixas vazões, na maioria dos casos até $2 \mathrm{~m}^{3} / \mathrm{h}$;

- teor de sais, em parcela significativa dos poços, superior ao recomendado para consumo humano;

- alto índice de poços secos, dadas as peculiaridades geológicas. 
Os poços perfurados no cristalino têm profundidade da ordem de 50 metros, ao passo que, nas bacias sedimentares, as profundidades são variadas, na maioria dos casos entre 100 e 300 metros.

Em um contexto mais amplo, os registros sobre cisternas e outras formas diretas de captação e armazenamento de água de chuva remontam a dois mil anos, em regiões como a China e o deserto de Negev, hoje território de Israel e Jordânia (Gnadlinger, 1999), passando posteriormente por experiências pré-colombianas dos povos astecas e maias. Iniciativas desenvolvidas na China dão notícia de construção de um milhão de cisternas em determinada região. Diversas iniciativas de Estados, prefeituras, União e entidades governamentais têm multiplicado o número de cisternas no Nordeste do Brasil. A Figura 7 mostra cisternas de placa típicas das executadas in loco por toda parte do semi-árido brasileiro.

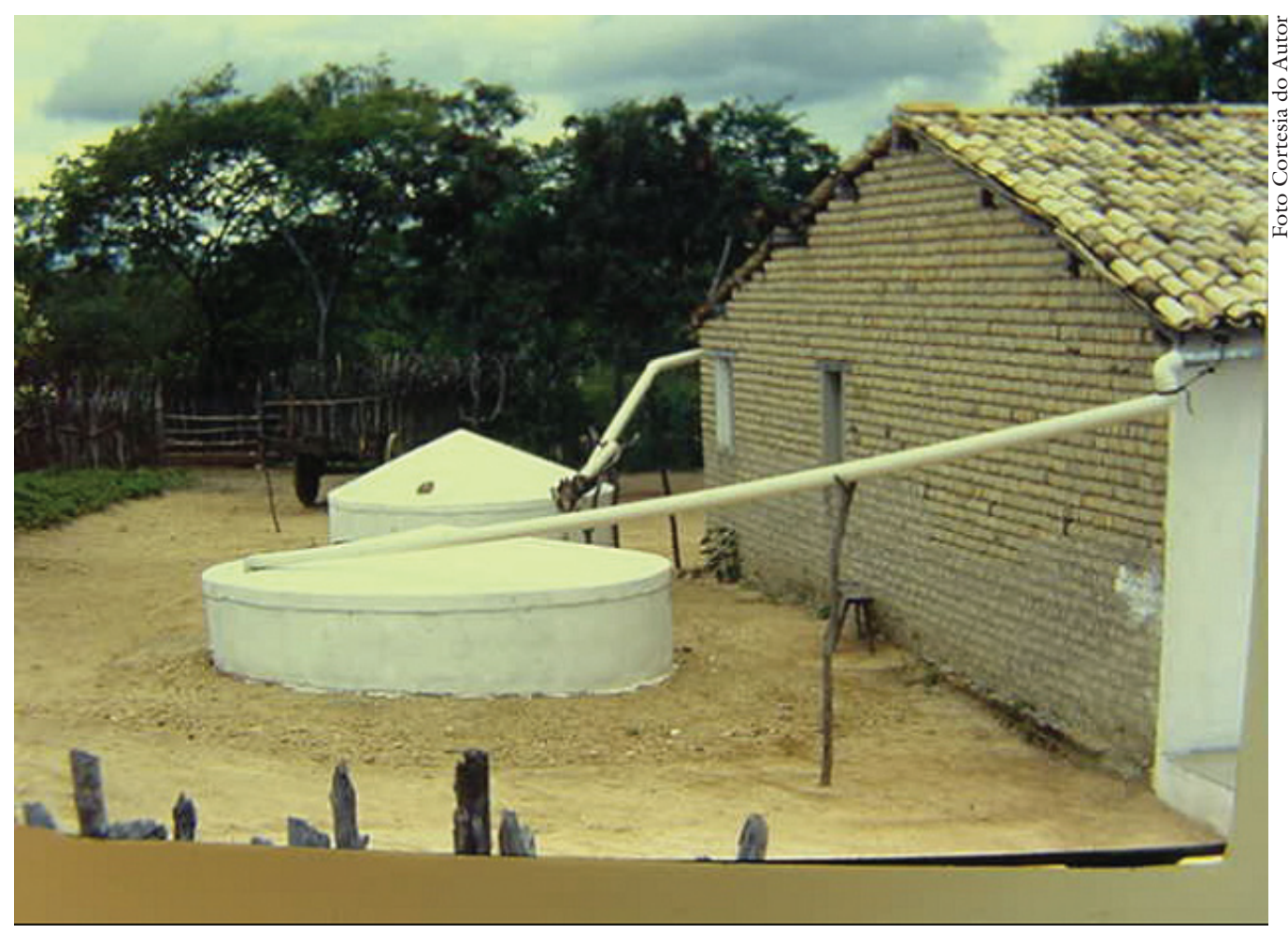

Figura 7 - Cisternas de placa e sistema de coleta de água do telhado.

As cisternas, com capacidade de acumulação normalmente entre 7 e 15 metros cúbicos, representam a oferta de 50 litros diários de água durante 140 a 300 dias, admitindo-a cheia no final da estação chuvosa e nenhuma recarga no período. Tomados os devidos cuidados com a limpeza do telhado, da cisterna, calha e tubulação, é uma solução fundamental para o atendimento das necessidades mais essenciais da população rural difusa. Embora existam aos milhares, espalhadas por todo o Nordeste, a quantidade de cisternas ainda é ínfima, quando comparada à necessidade da população rural. 
Em meados da década de 1990, experiências bem-sucedidas na construção e no manejo de pequenas barragens subterrâneas foram implantadas pela organização não-governamental Caatinga, no município de Ouricuri (PE), dando suporte à agricultura familiar na região. Em 1997, o governo de Pernambuco passou a admitir como um dos seus programas de Convivência com a Seca a construção de barragens subterrâneas no Agreste e Sertão do Estado (Costa et al., 2000). Com a implantação no Nordeste de mais um ciclo das chamadas frentes produtivas de trabalho em razão da seca que assolava a região, foram construídas em Pernambuco cerca de 500 barragens, cujos resultados precisam ser avaliados e monitorados. Paralelamente às ações técnicas, também é necessário um trabalho de capacitação da população beneficiada para que haja um melhor aproveitamento das águas disponíveis nessas obras hídricas.

Na Figura 8, apresenta-se a execução de uma dessas barragens subterrâneas, na fase de impermeabilização do eixo barrado para reter o fluxo de água no subsolo (Cirilo et al., 2003).

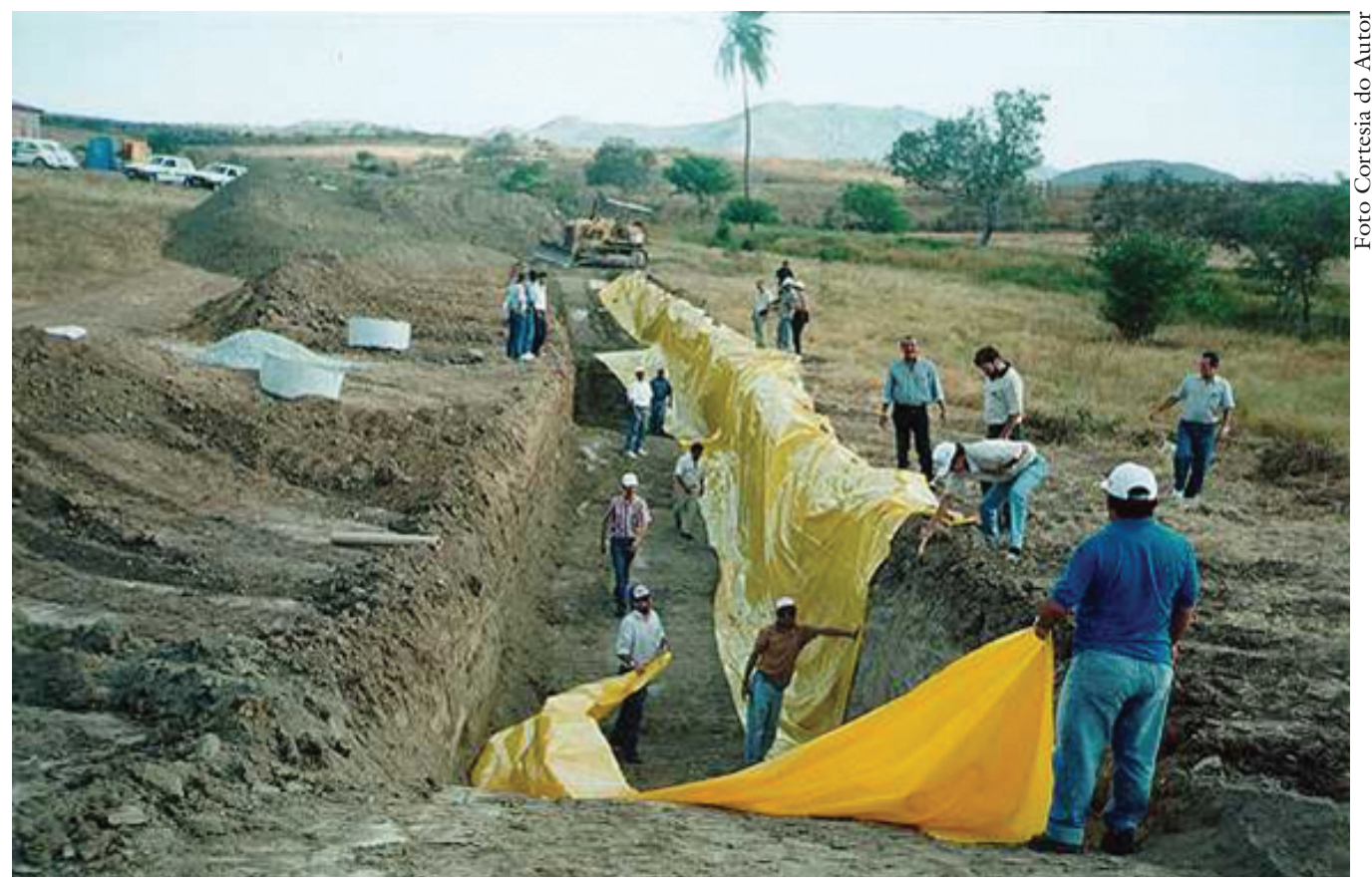

Figura 8

Construção de barragem subterrânea - escavação e colocação de manta impermeável.

Além da iniciativa governamental citada, ONG como Caatinga, AS-PTA e Diaconia vêm construindo barragens subterrâneas em parceria com os habitantes da zona rural do Nordeste, especialmente em Pernambuco.

\section{Dessalinização de água}

Em razão da má qualidade da água dos poços existentes no semi-árido nordestino, é grande o emprego de dessalinizadores dotados de membranas de 
Quadro 2

Opções de obtenção de água em pequenos imóveis rurais

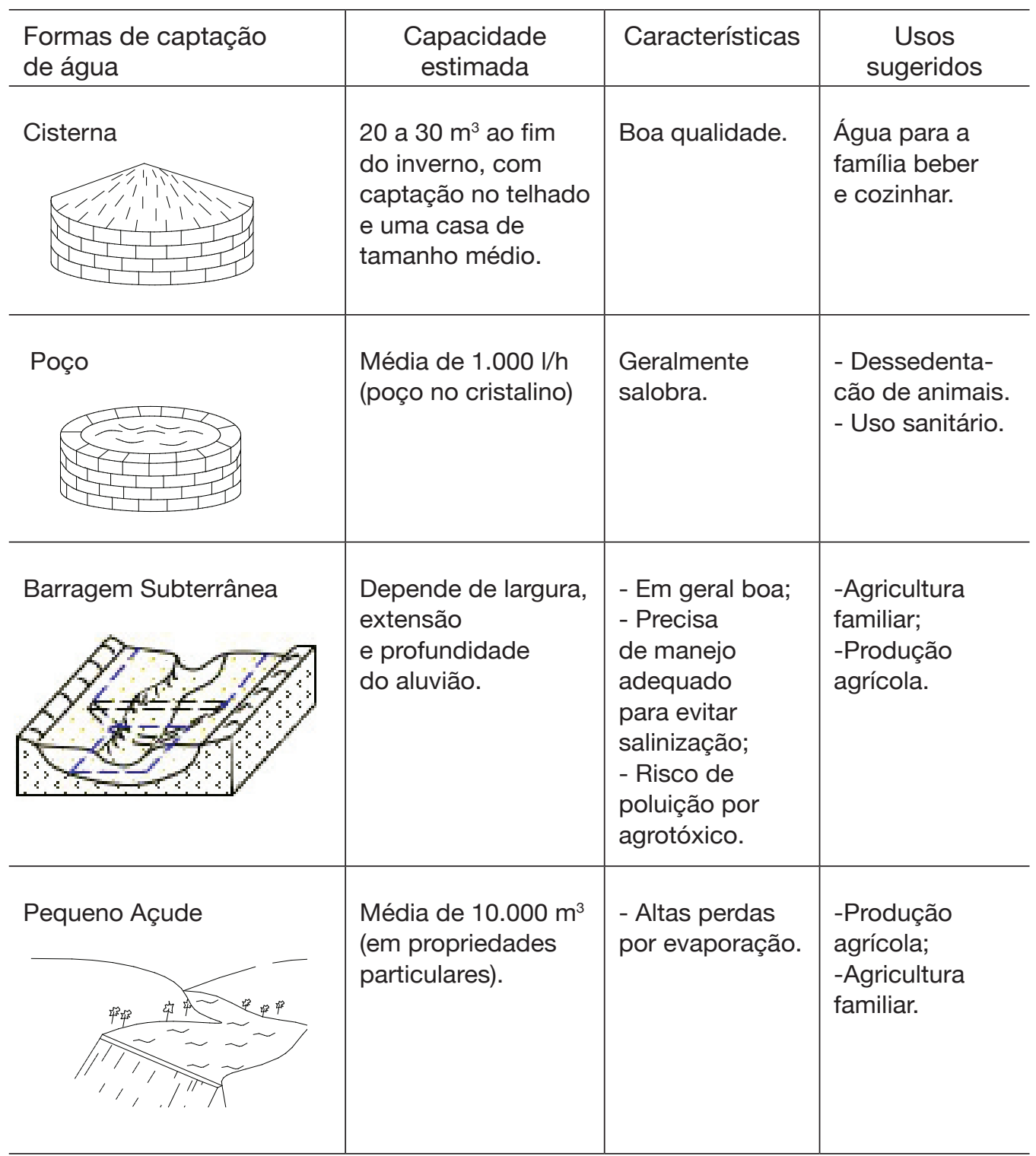

Fonte: Campello Netto et al. (2007, p.491).

osmose reversa para retirar parcela significativa dos sais presentes na água. Não obstante os dessalinizadores se mostrem eficazes na melhoria da potabilidade da água, problemas precisam ser gerenciados: destinação do rejeito proveniente da salinização, alto custo de manutenção e logística de operação complexa. Para a destinação do rejeito, algumas soluções têm sido adotadas, como: uso de tanques com lâminas d'água delgadas para incremento da velocidade de evaporação e a conseqüente deposição de sais; acumulação em tanques para a criação de 
peixes como tilápia rosa e o camarão marinho; o cultivo de Atriplex nummularia, planta com grande capacidade de absorção de sais, originária da Austrália e introduzida, com sucesso, no Chile, apresentando-se como uma excelente forrageira, que contém entre $16 \%$ e $20 \%$ de proteínas, e tem uma sobrevida de até vinte anos (Montenegro \& Montenegro, 2004).

\section{Reaproveitamento de águas servidas}

De forma geral, a destinação de esgotos ainda continua sendo os corpos d'água. No caso de baixo ou de nenhum nível de tratamento, as conseqüências são a poluição, as doenças de veiculação hídrica, a destruição da biodiversidade e a redução de água potável para o atendimento das populações e dos processos produtivos. A disposição de resíduos ricos em nutrientes, especialmente nitrogênio e fósforo, nos rios e outros corpos d'água, tem levado à eutrofização de mananciais e contribuído para floração de algas tóxicas chamadas cianofíceas, que se constituem em uma verdadeira praga para os reservatórios de abastecimento de água. Essas algas liberam toxinas (neurotoxinas e hepatotoxinas) que podem causar sérios danos à saúde humana, até mesmo a morte. O tratamento da água, além de difícil, é extremamente dispendioso.

Campello Netto et al. (2007, p.494) comentam que, em certos países, como Israel, razões culturais e déficit hídrico favorecem a aplicação de resíduos ao solo ao invés de descarregá-los nos corpos d'água. A aplicação de resíduos orgânicos na agricultura tem recebido maior atenção por causa dos custos e dos problemas ambientais associados com a disposição de resíduos, além, como citado, da baixa disponibilidade de água limpa para os processos de produção. No Nordeste, o reúso de água para atividades industriais vem surgindo em setores como produção de confecções. Ainda é muito tímida, praticamente resumindose a projetos-piloto, a reutilização de efluentes sanitários, tratados ou não, para atividades agrícolas.

\section{Transporte de água a grande distância}

No que se refere ao abastecimento humano nas cidades do semi-árido que não dispõem de mananciais próximos, a construção de adutoras é a solução mais adequada, seja a partir de reservatórios de maior porte seja a partir de poços em áreas sedimentares (com maior restrição para que sejam identificadas as potencialidades dessas reservas, no que tange principalmente aos mecanismos de recarga), ou mesmo a partir de rios e reservatórios mais distantes, mesmo em outras bacias hidrográficas, configurando-se as chamadas transposições de água entre bacias.

Grandes obras hídricas de transporte de água foram concluídas, estão em construção ou foram projetadas para abastecer as cidades do semi-árido e dar suporte às atividades produtivas nos últimos anos. É o caso, por exemplo, do Canal da Integração, no Ceará, destinado a conduzir água desde o reservatório de Castanhão, o maior do Nordeste fora da bacia do Rio São Francisco (capacidade de 6,7 bilhões de metros cúbicos) até a região de Fortaleza, ao longo 
de 225 quilômetros (Figura 9). Outro exemplo é a rede de 500 quilômetros de adutoras do Rio Grande do Norte (Figura 10). Em ambos os casos, trata-se de aproveitamento de reservas hídricas no território de cada Estado.

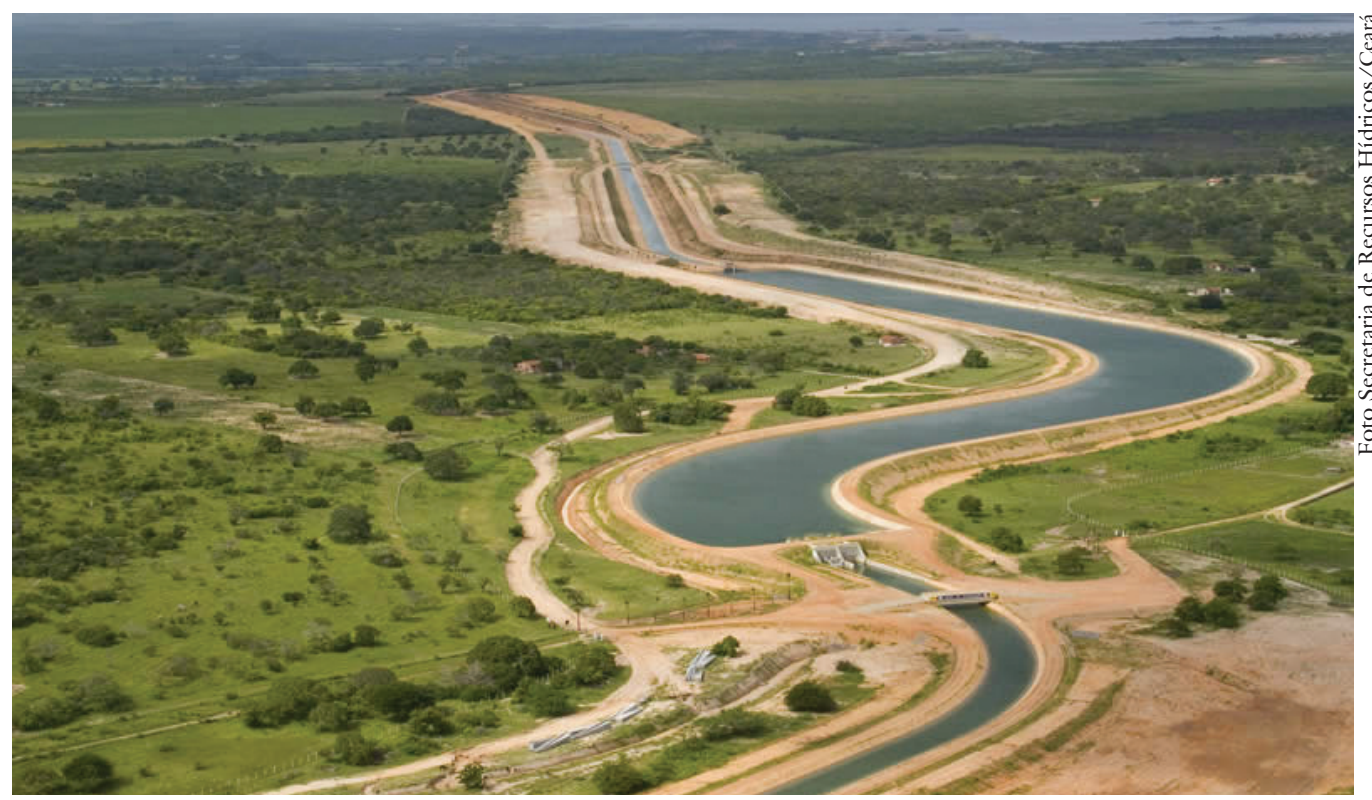

Figura 9 - Canal da integração, Ceará.

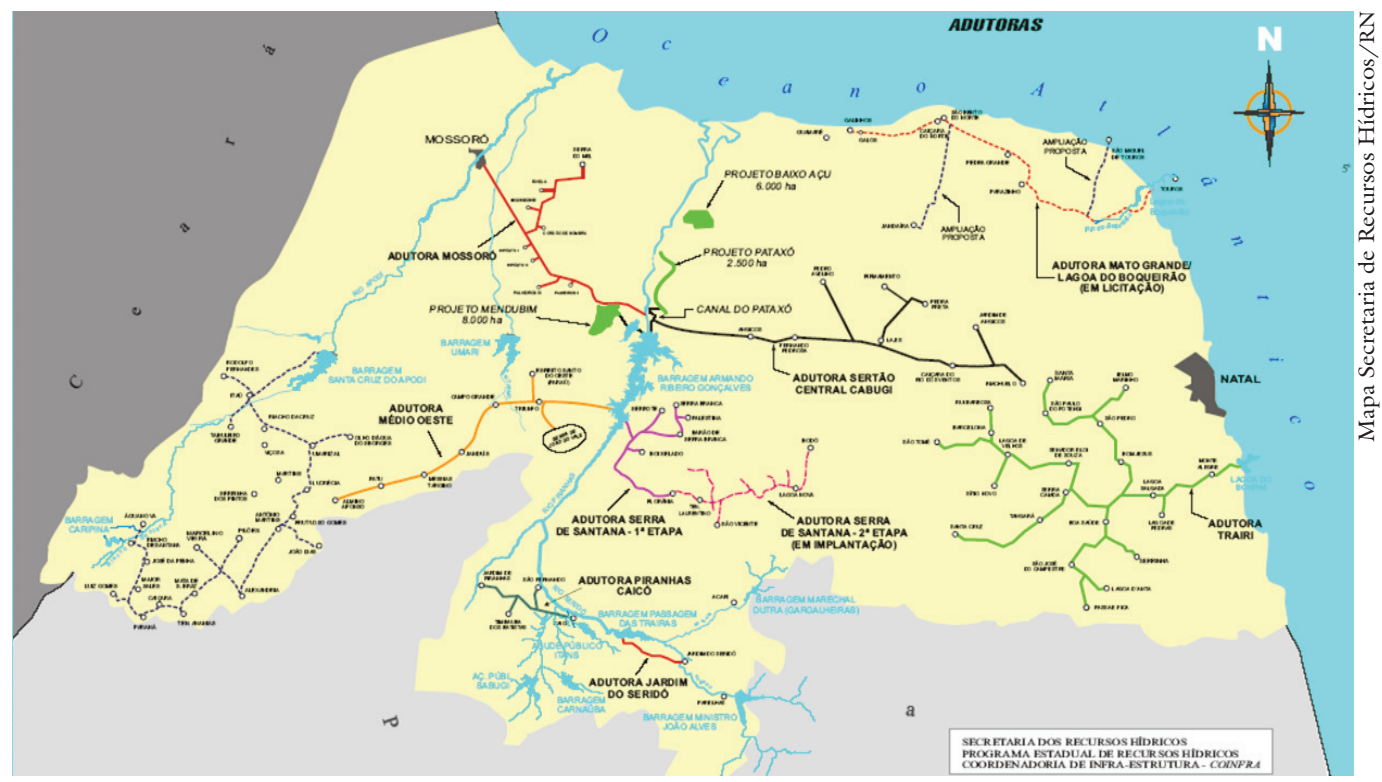

Figura 10 - Rede de adutoras do Rio Grande do Norte.

Outra situação hoje vivenciada é o início das obras para transposição de águas do rio São Francisco (Brasil, 2000) para os Estados do Ceará, do Rio Grande do Norte, da Paraíba e de Pernambuco (nesse caso, como dois terços do ter- 
ritório do Estado fazem parte da bacia do São Francisco, só se configura como transposição de águas a parcela que será destinada ao agreste pernambucano).

Segundo o Ministério da Integração Nacional, no horizonte final do projeto haverá retirada contínua de $26,4 \mathrm{~m}^{3} / \mathrm{s}$ de água, o equivalente a $1,4 \%$ da vazão garantida pela barragem de Sobradinho $\left(1.850 \mathrm{~m}^{3} / \mathrm{s}\right)$ no trecho do rio onde se dará a captação. Essa vazão será destinada ao consumo da população urbana de 390 municípios do agreste e do sertão dos quatro Estados do Nordeste setentrional. Nos anos em que o reservatório de Sobradinho superar sua capacidade de acumulação, o volume captado poderá ser ampliado para até $127 \mathrm{~m}^{3} / \mathrm{s}$, contribuindo para o aumento da garantia da oferta de água para múltiplos usos. A Figura 11 representa o esquema geral do projeto, evidenciando os Eixos Norte e Leste, estruturas principais do sistema, bem como reservatórios que deverão receber as águas e traçado aproximado das adutoras a serem interligadas.

O Eixo Norte foi projetado para uma capacidade máxima de $99 \mathrm{~m}^{3} / \mathrm{s}$ e deverá operar com uma vazão contínua de $16,4 \mathrm{~m}^{3} / \mathrm{s}$, destinada ao consumo humano. Os volumes excedentes transferidos serão armazenados em reservatórios existentes nas bacias receptoras: Atalho e Castanhão, no Ceará; Armando Ribeiro Gonçalves, Santa Cruz e Pau dos Ferros, no Rio Grande do Norte; Engenheiro Ávidos e São Gonçalo, na Paraíba; Chapéu e Entremontes, em Pernambuco.

No Estado do Ceará, o sistema de reservatórios que abastece a Região Metropolitana de Fortaleza (RMF) (açudes Pacajus, Pacoti, Riachão e Gavião) já está interligado ao Rio Jaguaribe através do Canal do Trabalhador (capacidade de $5 \mathrm{~m}^{3} / \mathrm{s}$ ). O Canal da Integração (capacidade de $22 \mathrm{~m}^{3} / \mathrm{s}$ ), já citado, interligará o açude Castanhão às bacias do Banabuiú (maior afluente do Rio Jaguaribe) e Metropolitanas.

No Estado do Rio Grande do Norte, o açude Armando Ribeiro Gonçalves é responsável pelo abastecimento de uma grande quantidade de municípios das bacias do Piranhas-Açu, Apodi e Ceará-Mirim por meio de quatro grandes sistemas adutores que estão em operação: Adutora de Mossoró, Adutora Sertão Central/Cabugi, Adutora Serra de Santana, Adutora do Médio Oeste. Em complemento, a Adutora do Alto Oeste, quando concluída, atenderá à maior parte dos municípios da bacia do Apodi, captando água no açude Santa Cruz, um dos reservatórios que deverão receber aporte de água do Projeto São Francisco.

No Estado da Paraíba, o Eixo Leste do Projeto São Francisco, de acordo com dados do Ministério da Integração, permitirá o aumento da garantia da oferta de água para os vários municípios da bacia do Paraíba, atendidos pelas adutoras do Congo, do Cariri, Boqueirão e Acauã. O Eixo Norte possibilitará a garantia de abastecimento de diversos municípios da bacia do Piranhas, atendidos por sistemas tais como Adutora Coremas/Sabugi e Canal Coremas/Souza.

No Estado de Pernambuco, os eixos Norte e Leste, ao atravessarem o seu território, servirão de fonte hídrica para sistemas adutores existentes ou em proje- 
to, responsáveis pelo abastecimento de populações do sertão e do agreste: Adutora do Oeste, já com a maior parte do sistema operando (estando os últimos ramais em licitação, as adutoras poderão ter reforçada sua capacidade de atendimento a partir de integração com o Eixo Norte); Adutora do Pajeú, com a primeira fase em licitação iniciada no princípio de 2008; Adutora do Agreste/Frei Damião, ainda em projeto e Adutora de Salgueiro, que opera há cerca de trinta anos e que, pelo crescimento da demanda, necessita no presente de complementação.

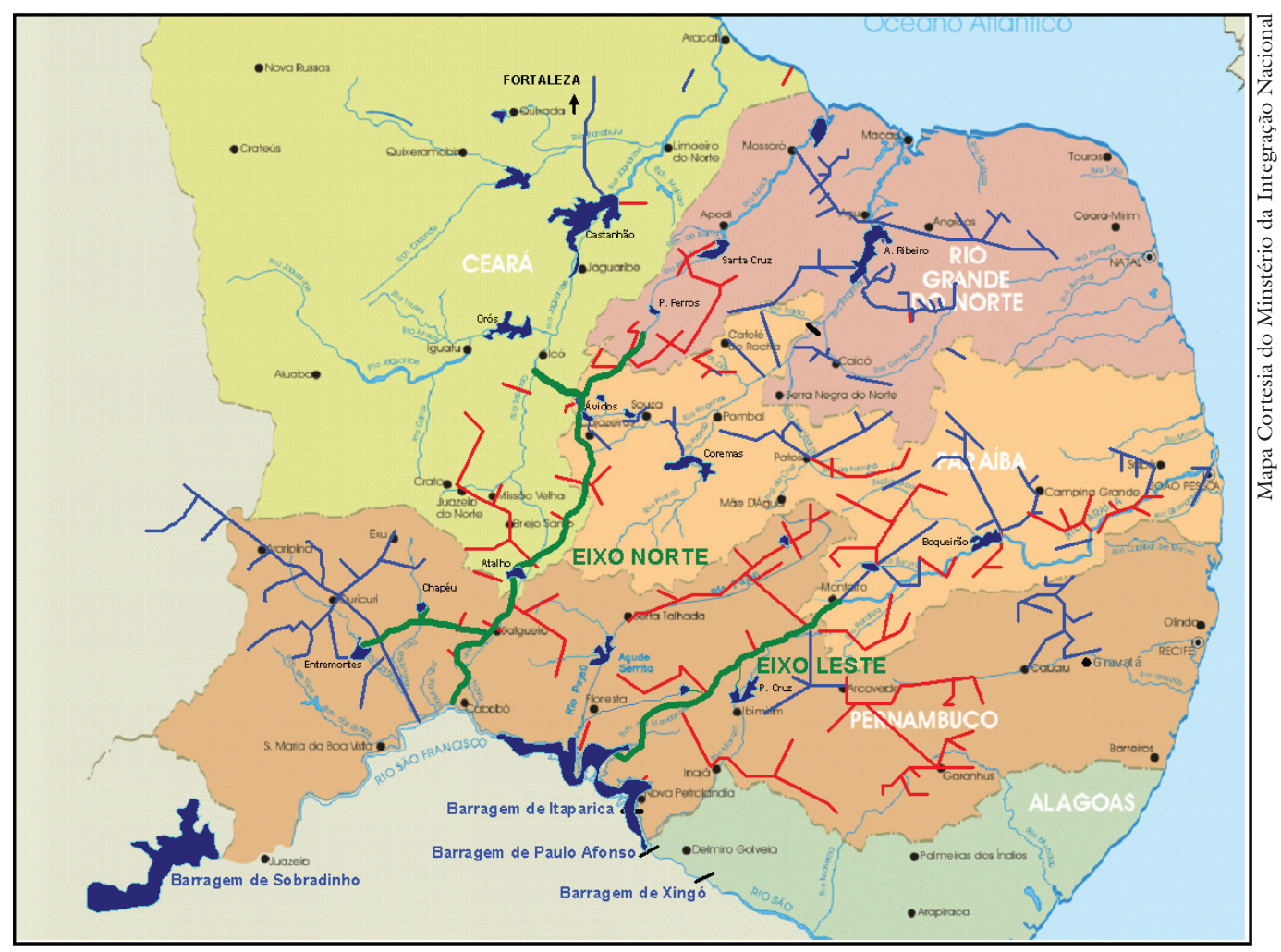

Legenda

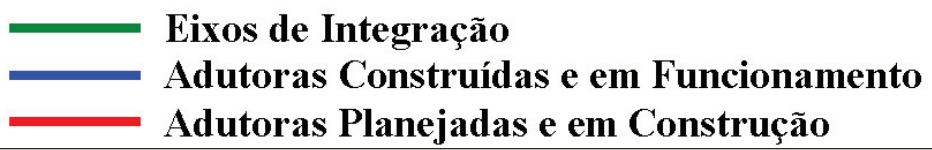

Figura 11 - Concepção geral do projeto - eixos, adutoras, reservatórios.

A Figura 12 representa a Adutora do Pajeú, destinada a aduzir 831 1/s para dezenove sedes municipais de Pernambuco, oito da Paraíba e distritos diversos próximos do traçado da adutora, e terá extensão aproximada de $600 \mathrm{~km}$.

O Sistema Adutor do Agreste (Pernambuco, 2008) terá extensão superior a mil quilômetros e deverá transportar cerca de $6 \mathrm{~m}^{3} / \mathrm{s}$ a setenta municípios e oitenta localidades da região agreste de Pernambuco. Esse sistema é mostrado de forma esquemática na Figura 13. 


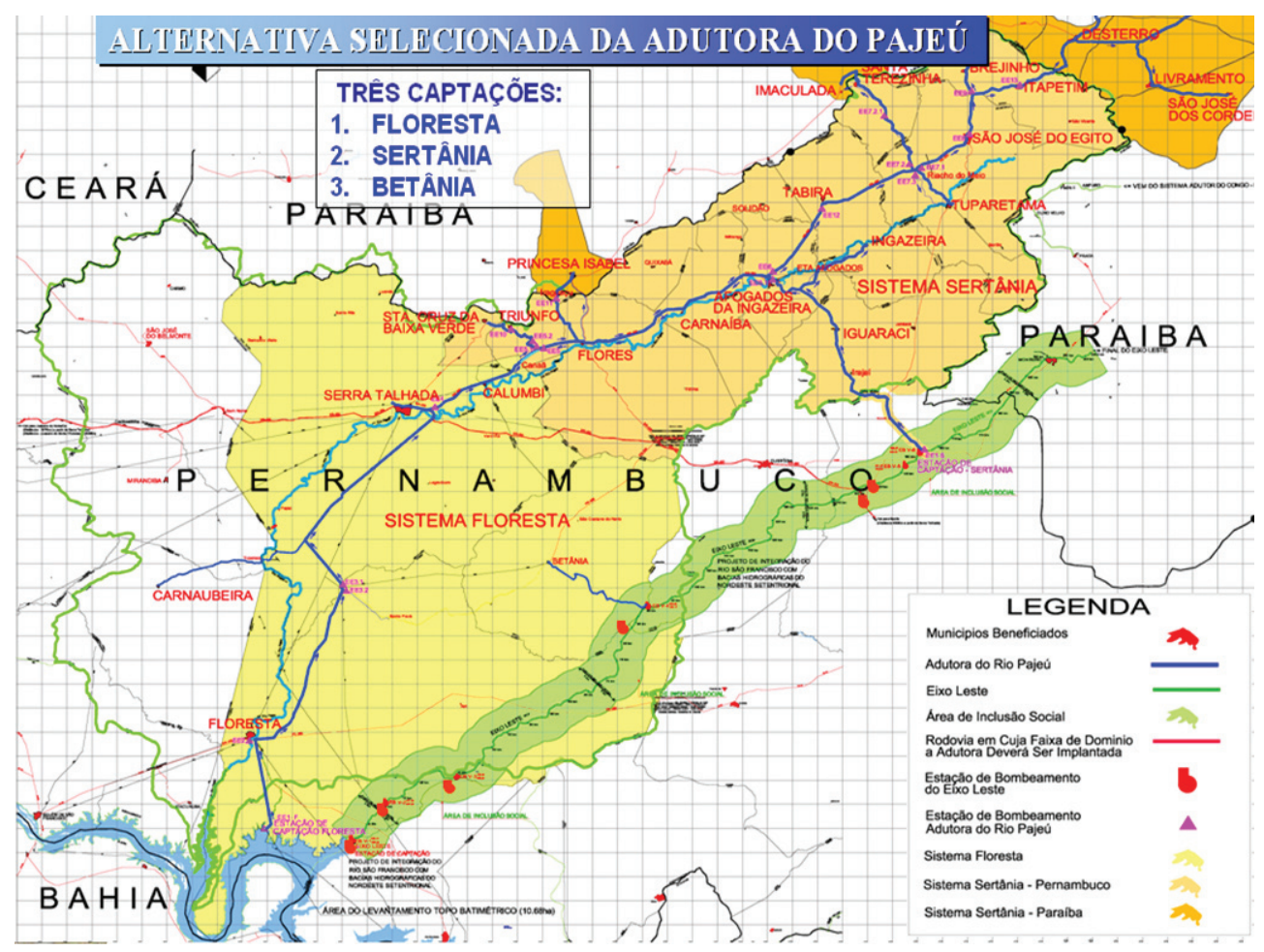

Fonte: Ministério da Integração/Dnocs.

Figura 12

Traçado previsto para a Adutora do Pajeú.

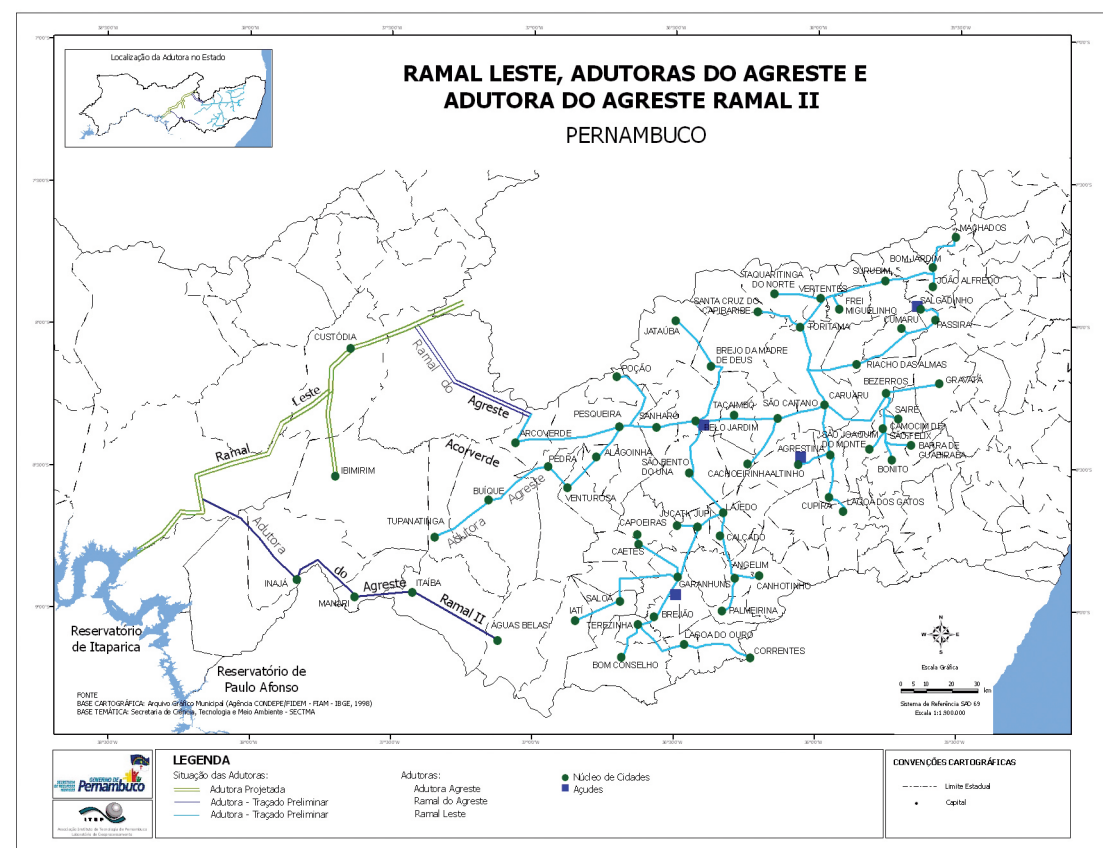

Fonte: Pernambuco (2008).

Figura 13

Traçado em fase de projeto para o Sistema Adutor do Agreste. 
É importante ressaltar o caráter polêmico do Projeto São Francisco, sobre o qual paira forte resistência no meio político, técnico, de organizações não-governamentais, de comitês de bacia e da população em geral, concentrada especialmente nos chamados "Estados doadores": Minas Gerais, Bahia, Sergipe, Alagoas e nas margens do São Francisco em território pernambucano. Os argumentos principais dizem respeito à prioridade que a União deveria dar à revitalização do São Francisco; à desconfiança quanto à necessidade de água nas bacias receptoras e dúvidas quanto à viabilidade econômica de implantação de projetos de irrigação previstos, ante os custos e as possíveis perdas de água no transporte; à crença de que não se fará justiça social nos projetos hidroagrícolas ao longo dos canais, com maior concentração de renda e da terra. Não há muita discussão quanto à pertinência de se transferir água do Rio São Francisco para abastecimento de água nas regiões fora de sua bacia, o que leva à oposição muito mais acirrada ao Eixo Norte que ao Leste, dada a prioridade neste último para o abastecimento de água. Por sua vez, o grande argumento a favor da transposição de águas do São Francisco, além do abastecimento humano, é que os reservatórios inseridos no projeto, destinados à irrigação, terão grande ganho sinérgico, dado que não necessitarão guardar água para os períodos secos e, portanto, perderão muito menos água por evaporação.

\section{Conclusões}

O semi-árido brasileiro apresenta situações mais difíceis de serem superadas do que as regiões de outras regiões semi-áridas do mundo. Aqui os solos são, em sua maior parte, muito rasos, com a rocha quase aflorante, o que compromete a existência de aqüíferos, sua recarga e qualidade das águas; temperaturas elevadas conduzem a altas taxas de evaporação; poucos rios perenes; concentração populacional das mais altas entre os semi-áridos do mundo geram pressões excessivas sobre os recursos hídricos.

A região apresenta, até a década de 1990, um histórico de políticas públicas equivocadas, quando não ausentes, calcadas especialmente na implantação de pequenos reservatórios altamente vulneráveis às estiagens e perfuração de poços no cristalino. Aliada a esses equívocos, a falta de gestão das águas foi a tônica da manutenção do quadro regional crítico a cada seca. Como forma de aliviar o sofrimento das populações desassistidas, as soluções de sempre: carros-pipa para transporte de água, frentes de trabalho para assegurar-lhes alguma renda para sustento. Em síntese, medidas puramente paliativas.

A partir dessa época, implantou-se nos Estados, com o suporte da União e da Lei n.9.433/1997, a chamada Lei das Águas, uma nova filosofia: controle do uso, por meio de instrumentos como outorga e da ainda incipiente cobrança pelo uso da água bruta; planos de recursos hídricos para as bacias hidrográficas e para os Estados; estruturação de entidades gestoras e organismos de bacia; programas de obras estruturadoras. Os maiores avanços na gestão dos recursos hídricos, comparando-se as regiões do país, vêm ocorrendo no Nordeste. 
Para atender às necessidades de água destinadas aos diversos usos, é importante que se entenda a particularidade das soluções. Não se pode imaginar que grandes canais e adutoras irão abastecer as populações rurais difusas, exceto aquelas próximas ao traçado das obras. Portanto, cisternas, pequenos reservatórios, poços, dessalinizadores devem ter seu uso ampliado e melhorado, particularmente na operação e manutenção.

Sobre a transposição de águas do Rio São Francisco, não há mais espaço para alimentar a discussão "contra ou a favor", dado que a obra é irreversível. Porém, para torná-la efetivamente útil para as populações a serem beneficiadas, muito planejamento é requerido. As questões operacionais do projeto devem ser mais estudadas, com a visão mais global de integração das fontes existentes e os cenários das esperadas mudanças climáticas. Questões como redução de perdas de condução de água e eficientização dos usos, principalmente na irrigação, onde os consumos são maiores, devem ser bem analisadas no projeto. Também precisam ser bem estudados os aspectos como distribuição da terra, cultivos a serem irrigados, infra-estrutura complementar e logística de escoamento de produção, pois a experiência de produção agrícola no Nordeste comprova que não é só a falta de água que compromete o desenvolvimento regional. Da mesma forma, os projetos já implantados ou previstos, na própria bacia do Rio São Francisco, necessitam ser estudados sob uma visão sistêmica e de futuro, porque são grandes as pressões sobre os recursos hídricos na bacia e muitas as potencialidades de conflitos de uso: particularmente no tocante à irrigação, há muito mais áreas que podem ser irrigadas que efetivamente água para isso.

Quanto à revitalização da bacia, entre outras iniciativas, devem ser estudadas as vazões ecológicas, ou regimes de vazões ecológicas, especialmente na foz do São Francisco, e implementar plano de operação das barragens para atender a essas condições. As ações de saneamento dos municípios da bacia, ora em implantação pelo governo federal ora pelos Estados, precisam ser complementadas por programas de revitalização do território: reflorestamento, proteção de nascentes, controle de erosão e outras ações.

Referências bibliográficas

ANA - Agência Nacional de Águas. Atlas Nordeste - Abastecimento urbano de água. Brasília, DF, 2005.

BRASIL. Ministério da Integração Nacional. Projeto de Transposição de Águas do Rio São Francisco para o Nordeste Setentrional. Brasília, DF, 2000. 10v.

. Ministério do Meio Ambiente - Secretaria de Recursos hídricos. Avaliação das Águas do Brasil. Brasília, DF, 2002. p.86.

Ministério da Integração Nacional/SDR. Relatório Final do Grupo de Trabalho Interministerial para Redelimitação do Semi-Árido Nordestino e do Polígono das Secas. Brasília, DF, 2005. p.33. 
BRASIL. Ministério da Integração Nacional. Câmara dos Deputados. Nova delimitação do semi-árido brasileiro. Estudo. Brasília, DF, nov. 2007. p.24.

CAMPELLO NETTO, M. S. C. et al. Manejo integrado de água no semi-árido brasileiro. In: CIRILO, J. A. et al. (Org.) O uso sustentável dos recursos hídricos em regiões semi-áridas. Recife: ABRH - Editora Universitária UFPE, 2007. p.508.

CIRILO, J. A. et al. Soluções para o suprimento de água de comunidades rurais difusas no semi-árido brasileiro. Avaliação de Barragens Subterrâneas. Revista Brasileira de Recursos Hídricos, p.5-24, 2003.

Integração das águas superficiais e subterrâneas. In: CIRILO, J. A. et al. (Org.) O uso sustentável dos recursos hídricos em regiões semi-áridas. Recife: ABRH - Editora Universitária UFPE, 2007. p.508.

COSTA, W. D. et al. Monitoramento das barragens subterrâneas no Estado de Pernambuco. In: V SIMPÓSIO DE RECURSOS HÍDRICOS DO NORDESTE ABRH/LARHISA, Natal, RN, 2000.

DEMETRIO, J. G. A. et al. Aqüiferos fissurais. In: CIRILO, J. A. et al. (Org.) O uso sustentável dos recursos hídricos em regiões semi-áridas. Recife: ABRH - Editora Universitária UFPE, 2007. p.508.

GNADLINGER, J. Técnicas de diferentes tipos de cisternas, construídas em comunidades rurais do semi-árido brasileiro. Anais do $1^{\text {o }}$ Simpósio sobre Captação de Água de Chuva no Semi-Árido Brasileiro, Petrolina PE, 1999.

MARENGO, J. Aquecimento global e as conseqüências das mudanças climáticas no Nordeste do Brasil. São José dos Campos: CPTEC/Inpe, 2007. p.54.

MONTENEGRO, S. M. G. L.; MONTENEGRO, A. A. A. Aproveitamento sustentável de aqüiferos aluviais no semi-árido. In: CABRAL, J. J. S. P. et al. Agua subterrânea: aqüiferos costeiros e aluviões, vulnerabilidade e aproveitamento. Recife: UFPE, 2004.

PERNAMBUCO. Secretaria de Recursos Hídricos. Plano Estratégico de Recursos Hidricos e Saneamento. Recife, 2008. p.112.

PROJETO ÁRIDAS. Nordeste: uma estratégia de desenvolvimento sustentável. Brasília, 1994. p.217.

REBOUÇAS, A. C. Água na Região Nordeste: desperdício e escassez. Estudos Avançados, São Paulo, v.11, n.29, p.127-54, 1997.

SUDENE. PLIRHINE - Plano de Aproveitamento Integrado dos Recursos Hídricos do Nordeste, Recife, PE 1980.

RESUMO - As características climáticas e socioeconômicas do semi-árido brasileiro requerem tecnologias específicas de utilização e conservação dos recursos hídricos. É preciso analisar as alternativas de obtenção de água para usos diversos. Em contraposição às formas tradicionais de acumular água em pequenos reservatórios de superfície (açudes) e perfuração de poços no cristalino, têm-se buscado alternativas como poços de grande profundidade nas áreas sedimentares, metodologias para redução da evaporação e controle da salinização, destinação e uso de efluentes. Por fim, obras de integração de bacias hidrográficas e transporte de água a grande distância começam a ser construídas na região. A abordagem dessas diferentes políticas hídricas para o semi-árido é o objetivo deste trabalho. 
PALAVRAS-CHAVE: Gestão dos recursos hídricos, Regiões semi-áridas, Políticas sustentáveis dos recursos hídricos.

ABSTRACT - The climatic, social and economic characteristics in the Brazilian semi-arid region require specific technologies of water resources uses and conservation. So, many alternatives for clean water acquisition must be analyzed. In opposition to the traditional way of accumulating water in small surface reservoirs and perforation of wells in crystalline terrains, alternatives have been looking like great depth wells in sedimentary areas, methodologies for evaporation reduction and salinization control, destination and use of effluents. Finally, works for river basins integration and water transport over long distances are starting to be built in Northeast region. The approach in those water policies for the Brazilian semi-arid region is the purpose of this paper.

KEYWORDS: Water resources management, Semi arid regions, Sustainable water policies.

José Almir Ciriloé professor associado da Universidade Federal de Pernambuco (UFPE) e secretário executivo de Recursos Hídricos do Estado de Pernambuco (PE).

@ - almir.cirilo@srh.pe.gov.br

Recebido em 17.6.2008 e aceito em 23.6.2008. 